$\mathrm{AO}$ は1.5倍付近が良り. (3)应大率を增す之全体の MTF が良くなるのは，受光系の影響を多く受け，悪化するの は焦点の MTFのためである。

\section{6. 拡大撮影時の情報量}

\section{久留米大学病院中央放射線部 \\ ○宮川照生・神崎好彦 河村誠治・城 浩介}

〔目的】現在, 拡大撮影は骨血管等の微細構造の観察 に用いられている．今回われわれは，乙の有用性を定量 的にとらえる試みを行ったので報告した。

[方法] skull のドライボーンに $\phi$ か, $2 \mathrm{~mm}, 3 \mathrm{~mm}$, $5 \mathrm{~mm}$ のセルロイドをトルコ鞍近傍に置き，乙れを疑似 の石灰化とした。これら，三種類を $\times 1 ， \times 2, \times 3$ の拡 大率で撮影し各々 250枚作成し，技師，脳外科医の各 4 名で 3 段階評価を行った。 (1)石灰化はない，(2)加らな い, (3)石死化はある。

〔結果】各々拡大での情報量を示すと, $\mathrm{T}(\mathrm{x} ; \mathrm{z}) \times 10$. $036 \times 20.025 \times 30.014, \mathrm{~T}(\mathrm{X}, \mathrm{Y} ; Z) \times 10.099 \times 20.185 \times$ $30.132, \mathrm{~A}(\mathrm{X} ; \mathrm{Y} ; Z) \times 10.025 \times 20.066 \times 30.020$ である. ただし単位は〔bits〕とする，以上から，2 倍拢大があ っとあいいと思われた。

座長集約 (13～16)

高尾義人（長崎大学医学部附属病院）

との演題群は四題全部が桩大ステレオに関するあので, それぞれ実用上有意義な報告であり，13では拡大ステレ オの焦点間距離, 多重絞り等の問題点を, 14では散乱線 の増感紙およびグリッドによる変化を明らかにした。 15 は拡大で焦点の MTFが悪くなり, 受光系（増感紙フィ ルム）のそれが良くなるなかで，それぞれの組合せ時の

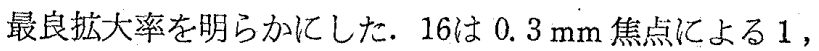
2,3 倍拡大写真が 8 名の評洒で $3,2,1$ 倍の順序仙 なる之報告した。

\section{7、マイコンでの腔内照射線量分布図の作製}

長崎市立市民病院放射線部

○平 邦夫・瞗長陽一

長崎市立市民病院産婦人科田川博之

マイコンIF800を使用し，ラルストロンの線量分布図 作成と，治療計画の最適化を行うプログラムを組んで， 良い結果を得たので報告する。分布図作成には，92× 110 己 $23 \times 36$ のマトリックスサイズを用意している。治 療計画の最適化は, タンデム 3 点と両オボイドの線源 5 点で行い，まずライトペンで，望む線量分布の概略図を 10点プロットし，それに近い分布を得るように，諸フォ クターの值をコンピュータが計算し最適化を行う。これ
には，ある程度の条件を計画者が入力してやる方法と， 幾何学的条件以外は全て, コンピュータか調整し, ファ クターを決定する 2 法が有る. 結果として, 治療計画者 にとり，便利な道具となっている。

18. 子宮癌腔内照射における直腸への被曝低減について 長崎市立市民病院放射線部

○長尾栄一・平·邦夫・嶋長陽一

子宫痹の腔内照射治療時, 直腸への被曝低減をはかる ため，オボイドアプリケータの改造を行り好結果を得た ので報皆する.オボイドアプリケータ先端の半球部，ア ルミ合金低辺部を $6 \mathrm{~mm}$ 水平方向にカットし，その部分 に $8 \mathrm{~mm}$ 厚さの鋁板を附着し表面をグラスファイバーで 被㠅鉛加ら発生する軟線吸收はかった。改造前, 改造 後のアプリケータを使用グラフィックフィルムに露光し て等線䑁曲線を求め比較した結果計算上掞よび実験的に 6、直陽線量は60\%弱之なり現在值腸障害をそれほど気に するととなく照射するととができるようになった，尚今 後恃膀胱への被曝線量む低減させるため, 上方手何らか の形で改造し棈円状の分布を得たい之思っている.

\section{Remote after Loading（ラルストロン）線源の最} 適平面化と線量について（第 1 報）

九州厚生年金病院

○鈴木满明・岡部健吾・近藤正美

〔目的〕子宮頸癌の腔内照射にA点, B点という基準 点線量で表示されている，実測を行う場合に子宮軸の一 平面上のみになってしまう。臨床的には子宮前屈, 後屈 等があり，オボイドの位置も一平面上にない場合が多 い. そとで最適平面を設定し，子宮軸にそった平面と最 適平面での線量と分布図について比較検討を行った。

〔結果〕1)、ボイドが子宮口より $1 \mathrm{~cm}$ 下方にずれ た場合を最適平面化すると，子宮軸線量を100\%にした 場合，A点で $94.5 \%$ ， B 点で $95.7 \%$ となる，2）タンデ ムが30度後屈した場合 $\mathrm{A}$ 点で $94.1 \% ， \mathrm{~B}$ 点では $92.7 \%$ と なる．３）タンデムが30度後属し，オボイドは子宮口よ り $1 \mathrm{~cm}$ 下方にずれた場合 $\mathrm{A}$ 点で $102.7 \%$ ，B点で $92.7 \%$ となった。

20.「密封小線源による被曝」第一報 ラジゥム針組織内照射における胎児の被晎線量の推 定

九州大学医学部附属病院放射線部 ○進藤順二

〔目的・方法〕妊娠 8 ケ月の患者に対するラジウム針 組織内照射（Ra $19 \mathrm{mg}, 168 \mathrm{~h}$ ) 《おける胎児被曝線量 を,ファントム実験および治療時の測定により推定を試 
みた。

〔結果】人体ファントムを用いた測定では，0.65〜 $1.2 \mathrm{mrad} / \mathrm{mgh}$ となり, 当治燎的飞換算すると $2 \sim 4 \mathrm{rad}$ の胎坚被嚗と推定されたが，患者治燎時の測定では， 2 $\mathrm{mrad} / \mathrm{mgh}, 6.6 \mathrm{rad} / 19 \mathrm{mg} \cdot 168 \mathrm{~h}$ となった。 乙れは，患 者の体位，装着した TLD 素子の移動などによる，over estimationではないかと考えられるがさらに「MIRD法」 による線量推定を試みたい。

\section{1. 電子線腔内照射用ッーブスの線量分布}

産業医科大学病院放射線部

○小正人・吉浦隆雄

従来使用されている電子線腔内照射用ッーブスは，金 属製で，側視鏡下の観察を必要とし，不正確になり易い 欠点がある. 今回，直視下での位置決めが可能なアクリ ル簑ツーブスを試作し，比較検討した結果，出力線量お よび表面線量・エネルギー・ビルドアップ域とも，大差 なかった．また，最も問題となるッーブス外漏洩線にお いても，遮橵用鉛のつばの使用に上り，2〜6\%に軽減 できた. 製作費も金属ツーブスの 4 分の 1 というとと息 あり，充分使用可能である.

\section{2. 電子線による全身照射}

宮崎医科大学医学部附属病院中央放射線部

○鈴木 徽・高田卓雄

斉藤 勲・上田正美

従来, 菌状息肉腫は,ッーブスを用いて軟X線や電子 線治療がなされてきた。しかし，照射野のつなぎ目で過 照射および線量不足になる久点がある。本報告は，ライ ナック（8 MeV の電子線）を用いて全身に均一に照射す る方法を検討したものである.

その結果，(1)突質的な電子線のエネルギーを低くする ために，照射口にアクリル $(1.5 \mathrm{~cm})$ を村加する.(2)体 軸方向に $3 \sim 4$ 閒照射を行う. (3)横断面については，正 中矢状面に対してへッドを $45^{\circ}$ 傾けた 4 閔照射を行う， ことによって全身に均一な，しかる皮雐に限局した線量 分布が得られることがわかった。

座長集約 $(17 \sim 22)$

$$
\text { 熊谷孝三（国立病院九州がんセンター） }
$$

演題17〜19の3 3 笠はりモートアフタローダに関する報 告である．演題17は市販のパリコン利用による線量分布 図作製の報告であり，すでに多くの報告がある。演題18 はオボイドアプリケータ改造による直腸線量低減につい ての報告であるが，タンデムおよびオボイド各線源の組 合せによる基本的線量分布を考慮に入れ，実測等により 直晹線量を把握したい，演題19は湖々の線源すべてを含
む最適平面を設定し，従来の子宮軸にそった $\mathrm{A}$ 点線量お よび線量分布を比較している. とてでA点の定義が問題 となるが，線量評洒の一手段として今後期待すべきすの がある。

演題20はラドウム針組織内（舌）照射による胎児被曝 線量を患者の実測とファントムの測定の両者から推定を 行った報告であり，患者実測からの被曝線量推定值の方 がより多く，乙の原因は治療中の患者体位変化倸上るも のとしている，今後，白血病の誘発などの晚発障害が問 題となろう。

演題21は直視下で位置決め可能な腔内用ッーブス試作 の報告である．從来の不透明金属ッーブス之物理的諸条 件は変わらず，直視下での位置決めが容易な点が有利で あるとしている。

演題22は電子線の全身照射についての報告であり，体 軸方向にガントリを 45 度傾斜する 4 門照射により良好な 線量分布が得られている。乙こで，菌状息肉腫は電子線 照射に上る体表面治燎が対象であるから，乙の場合は電 子線による全身体表面照射の方がより適切であり，全身 照射という表現は高エネルギーX線に限定したい。

23. 診断用 $\mathrm{X}$ 線撮影装置および $\mathrm{C}$ 形アーム式 $\mathrm{X}$ 線テレビ 装置を応用した簡易シュミレータの試作

国立熊本病院放射線科

○永広順治・米村正智

放射線治療計画に不可欠なシュミレータが末設置の施 設は，独自の方法で位置決めをされていると思われる が, 当院比いても自作の簡易シュミレータを考案し作 製したので報告する。一般撮影装置およびしアーム式テ レビ装置の，X線管焦点㧍よび病巣間距離の中点に，目 盛扔よび照射範因を示すバーををなえたスケーラーを， 装着できるようにしたものである。乙れは，病䉓面にお 汀る照射野が正確に決定でき，スケーラーは脱着可能な ので, 本来の装置の機能は全く損なわず，低コストで， スペース的にあ増改築の必要がなく，概存の撮影および 透視等の装置にスケーラーを装着することにより，簡易 シュそレーターとして利用できる。

\section{RH-5 改造型シミュレータについて}

北九州市立小倉病院

$$
\text { ○吉瀬孝志・原本輔一・ 丸山誠一 }
$$

〔目的〕シミュレータと治療装置とは運動機能, 精度 等が全く同じであるととが理想的であり，また，TV 映 像, 計測等についても充分认カバーリングさせるため, 大型14インチ I.I の使用等, その機能の拡大を謀る目的 で RH- 5 型を改良したので報告する. 